\title{
COMPARATIVE ANALYSIS OF EXPORT CAPABILITIES OF THE METALWORKING INDUSTRY IN ZLATIBOR REGION AND THE REST OF SERBIA
}

\author{
UDC: 669:339.564(497.11) \\ Original Scientific Paper

\section{Vesna K. SPASOJEVIĆ BRKIĆ ${ }^{1}$, Zorica A. VELJKOVIĆ ${ }^{2}$, Tamara GOLUBOVIĆ ${ }^{2}$,} \\ Aleksandar Đ. BRKIĆ ${ }^{3}$, Sonja JOSIPOVIĆ ${ }^{2}$
${ }^{1}$ University of Belgrade, Faculty of Mechanical Engineering, Industrial Engineering Department, Kraljice Marije 16, Belgrade, Republic of Serbia
E-mail: vspasojevic@mas.bg.ac.rs
${ }^{2}$ University of Belgrade, Faculty of Mechanical Engineering, Industrial Engineering Department, Kraljice Marije 16, Belgrade, Republic of Serbia
${ }^{3}$ University of Belgrade, Faculty of Mechanical Engineering, Innovation Center, Kraljice Marije 16, Belgrade, \\ Republic of Serbia
}

Paper received: 13.04.2016.; Paper accepted: 14.05.2016.

\begin{abstract}
Exporting is very important activity for companies settled in developing countries, while manufacturing industry is the most important section of the EU economy that drives its growth and propels its technological and innovation development, so it is expected that export in that sector is extremely important activity from national economy point of view. Accordingly, the topic of this survey deals with export possibilities of metalworking industry and compares Zlatibor region export capabilities to export capabilities of the rest of Serbian metalworking companies to EU. There aren't many significant distinctions in export capabilities of Zlatibor region and the rest of Serbia, and they are mainly related to knowledge of regulations. Namely, a significant number of companies is not familiar with new approach directives, as well as with procedures for conformity assessment. Recommendation is more careful choice of suppliers that satisfy necessary requirements, too.
\end{abstract}

Keywords: Export to EU market, Formal requirements for export, Differences, Barriers for export.

\section{INTRODUCTION}

Companies' survival, expansion and the consequent economic growth on the country level depend on companies export performance (Stoian, Rialp \& Rialp, 2011). Accordingly, exporting is very important activity for companies settled in developing countries since it strengthens competitive capacities, provides higher profit, diversifies business risks on multiple markets, generates more funds for investment and external, higher wages and internal market development, increases domestic employment levels and, finally, leads to higher standards of living in home country (Leonidou et al., 2007 and 2010, Lee et al., 2004, Bonaccorsi, 1992, Donthu \& Kim, 1993, Papadopoulos, \& Martín 2010). The need for standard of living upgrade in small open economies could be satisfied through international exchange (Baldauf, Cravens, \& Wagner, 2000). Also, manufacturing industry is the most important sector of the EU economy - it drives its growth and propels its technological and innovation development (Jakopin \& Bajec, 2009), so it is expected that export in that sector is extremely important activity from national economy point of view (Basile, 2001).

Accordingly, the topic of this survey deals with export possibilities of Serbian companies in metalworking industry. Since, Zlatibor region has recently increased its export toward Russian Federation for $300 \%$, the aim of this paper is to compare Zlatibor region export capabilities to export capabilities of the rest of Serbian metalworking companies to EU . Export of 
products and services on European Union market can bring great benefits to the companies and the national economy, but also set requirements to companies which are not easy to meet (Spasojevic Brkic et al, 2014). Spasojevic Brkic et al. (2015) notice that canton of Sarajevo and Zlatibor district are recognizable by metal complex, which intends to adjust to new conditions and challenges of international market.

Khara \& Dogra (2009) point out that the exporters face many constraints on their road to succeess which can be classified into financial (availability and cost of finance), marketing (export marketing, export packaging and creativity), technological (related to access and quality management) and inputs (availability of skilled labor and raw materials). Kumlu (2014) adds that it is very important for the companies that are looking for better export results to pay more attention on developing intangible resources to reach desired export performance. Knudsen \& Madsen (2002) propose that traditional export strategy research today transfers towards a dynamic capabilities perspectives analysis, while Basile (2001) adds that for export behavior of Italian manufacturing firms the role of innovation is crucial.

Serbian metalworking companies are involved in the fallowing sectors: 1. Extracting metal ore, 2. Production of base metals, 3. Production of standard metal products, not including machines or devices, 4. Production of machines and devices, 5. Production of electric and optic devices, 6. Production of traffic means, 7. Production of other traffic means, 8. Other processing industry (metal industry includes only recycling of used raw materials in this section and excludes production of furniture and other similar products). Metal industry companies have been the core of Serbian industry during past decades. Since the early 1980 s Serbian economy has had problems with improving quality and productivity (Đorđević et al., 2011), and today it is characterized by a large number of week companies which are in the process of reorganization and by a trend of decrease in the average size of enterprises (Cockalo, 2011). For this reason, small and medium enterprises are increasingly becoming the examples of productivity and efficiency in a way that every day more such companies record impressive business results and a very solid profit margin. Anyway, fulfilling the requirements for export to the EU market is a difficult challenge for metal industry companies in Serbia (Spasojevic Brkic et al., 2015), although it shares strong commitment towards EU integration. According to data from Užice Regional Chamber of Commerce web site, overall international trade of the Republic of Serbia, for the period from January to December 2015, was 31,6 billion dollars, which represents a $10,9 \%$ of decrease when compared to the same period from last year. Exported good are estimated to 13,4 billion dollars, which represents a $10 \%$ of decrease when compared to the same period from last year, while imported goods are estimated to 18,2 billion dollars, which is $11,6 \%$ of decrease comparing to the same period from last year. International exchange from Zlatibor region in the same period was 1.127 billion dollars, from which export was 607 billion dollars and import 520 billion dollars, while surplus amounted to 87 billion dollars and import/export ratio was $117 \%$.

\section{METHODS AND FINDINGS}

\section{Sample and Survey method}

The survey questionnaire was developed after a review of the literature, in-depth interviews and pre-testing using knowledge of experts in the field. To conduct survey Google docs e-mail query instrument has been used. Previously, 400 domestic companies from metalworking industry were invited via e-mail to participate in the survey. 46 companies responded, from which 10 were from Zlatibor region. Mean value of number of employees in the companies in the sample is similar and between 155 and 174 .

Table 1: Descriptive statistics of the sample of companies that participated

\begin{tabular}{|l|l|l|l|l|l|l|l|}
\hline & Valid N & $\begin{array}{l}\text { Mean no. } \\
\text { of } \\
\text { employees }\end{array}$ & Median & Minimum & Maximum & Std. Dev. & Coef. Var. \\
\hline No. SRB & 46 & 159.848 & 25.0 & 2 & 2700 & 442.22 & 276.65 \\
\hline No. ZL & 10 & 174.500 & 64.5 & 5 & 1005 & 307.61 & 176.28 \\
\hline No. SRBo & 36 & 155.778 & 22.5 & 2 & 2700 & 476.47 & 305.86 \\
\hline
\end{tabular}


Coefficients of variation of all variables are greater for $30 \%$, which means that data are nonhomogeneous. Hence, for comparison $\mathrm{U}^{*}$ test Man-Withney is used.

Table 2: U*test Mann-Withney for companie size
\begin{tabular}{|l|l|l|c|}
\hline & $\mathrm{U}^{*}$ & $\mathrm{z}$ & $\mathrm{p}$-level test \\
\hline Company size SRB-BIH & 0 & 0 & 1 \\
\hline Company size ZL-neZL & 0 & 0 & 1 \\
\hline Company size SA-neSA & 0 & 0 & 1 \\
\hline Company size ZL-SA & 0 & 0 & 1 \\
\hline
\end{tabular}

Man-Withney tests in table 2 show that there isn't a significant difference in the size of companies between the Zlatibor region and the rest of Serbia. This indicates that selected companies' sizes are evenly distibuted among the regions involved in survey.

Figure 1 shows what percentage of all surveyed companies were from Zlatibor region.

When observing samples of the companies in this research, it can be seen that companies from Zlatibor region are distributed through subsectors in a different manner than companies from the rest of the Serbia (figure 2), with significant differences (table 3). Base metal production companies (2) are similarly distributed on both fields but production of standard metal products, not including machines or devices (3) is more prevalent in Zlatibor region than in the rest of Serbia. On the other hand, production of machines and devices $(4-$ which is absent in Zlatibor region) is most prevalent sector in the rest of Serbia.

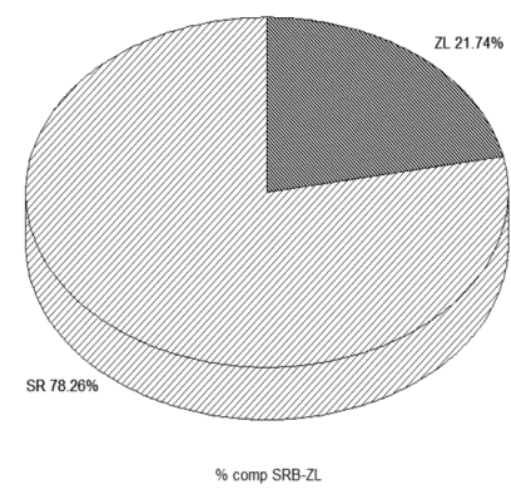

Figure 1: The percentage ratio of surveyed companies in the Zlatibor district and the rest of Serbia

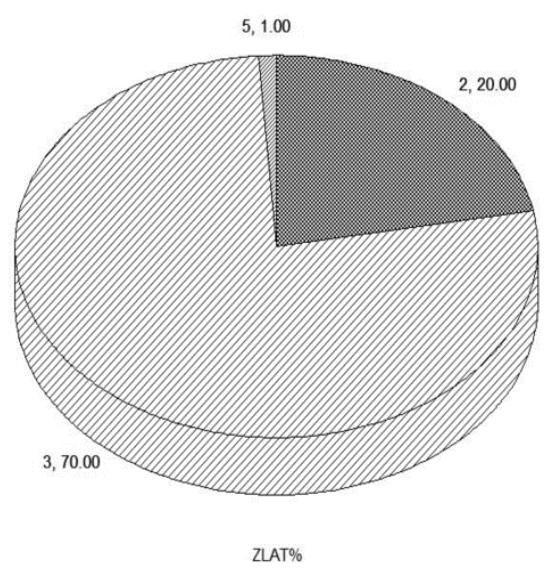

(b)

(a)

Figure 2: Subsectors distribution of a) Serbia and b) Zlatibor region

Table 3: Comparison of subsectors distribution of the companies from Zlatibor region and rest of the Serbia

\begin{tabular}{|l|l|l|l|l|}
\hline SRBo & & ZL & significance & $\mathrm{p}$ - level \\
\hline p3so & $<$ & $\mathrm{p} 3 \mathrm{z}$ & $*$ & 0.0133 \\
\hline p4so & $>>$ & $\mathrm{p} 4 \mathrm{z}$ & $* *$ & 0.008 \\
\hline
\end{tabular}

\section{Export capabilities of the metalworking industry in Zlatibor region and the rest of Serbia}

Distribution of number of ISO 9001 certified companies is not significantly different for Zlatibor region comparing to the rest of Serbia, as shown in figure 3 . 
Also, about half of companies from both regions have no attention to introduce new standards in the future, like ISO 14001, 18001,etc, as shown in figure 4 .

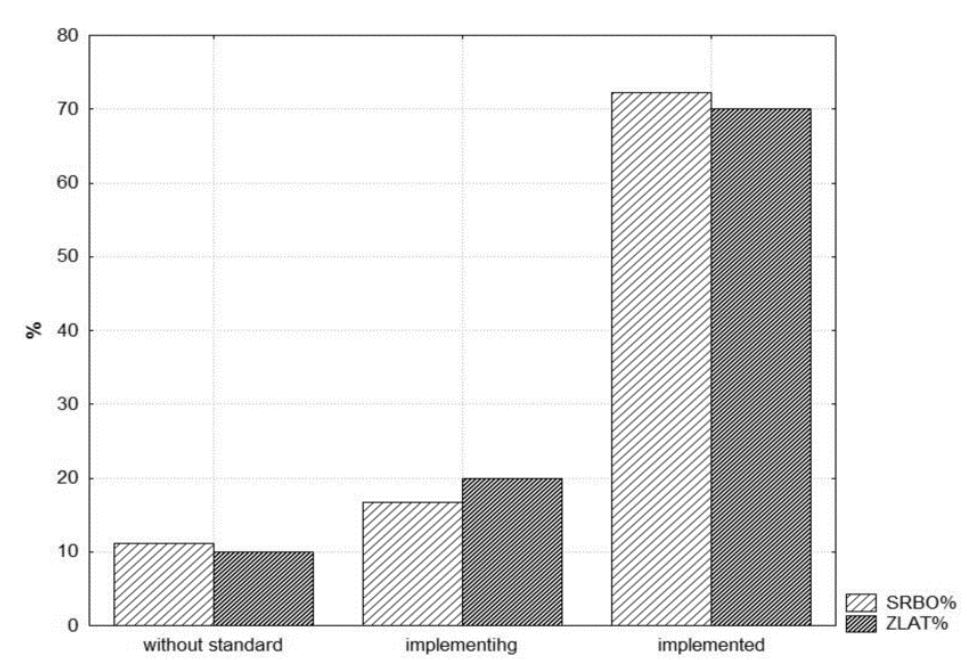

Figure 3: Comparison of number of ISO 9000 certified companies in Zlatibor region and the rest of Serbia

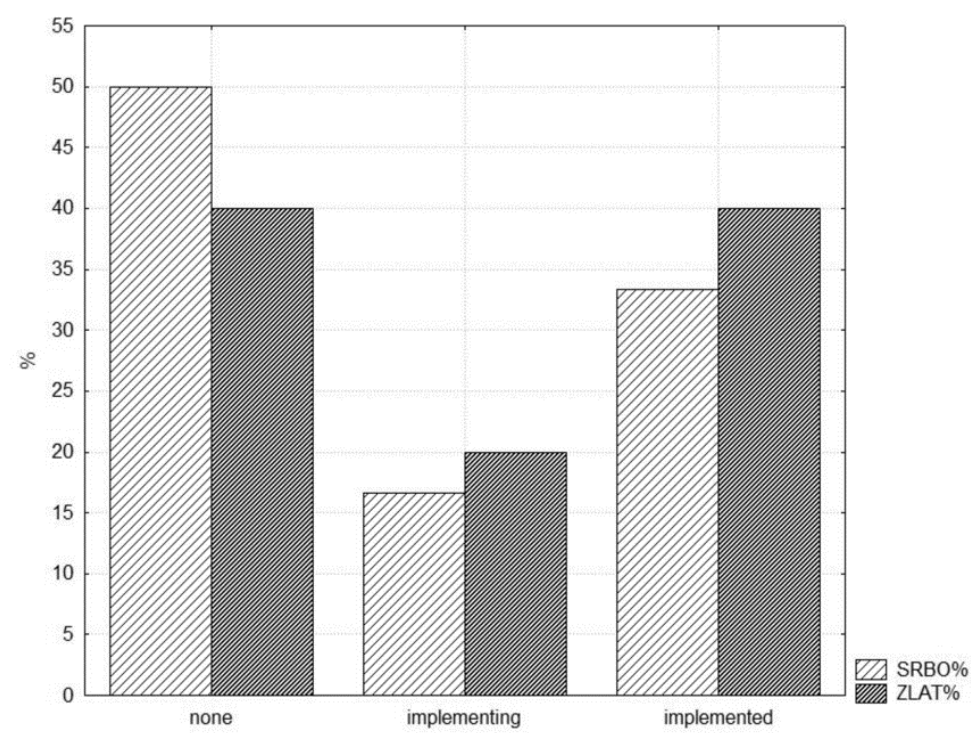

Figure 4: Certified systems according to ISO standards 14001, 18001 and other in companies from Zlatibor region and the rest of Serbia

Financial status of companies from Zlatibor region and the rest of Serbia shows that most of them belong to average group, and that there is no significant difference between two regions in this area. Investment in training courses and employees development is also similar in Zlatibor region and the rest of Serbia. In Zlatibor region companies do not invest in training of employees as much as they could, but large percentage $(40 \%)$ of them invests enough (grade 4 on the scale from 1 to 5 ). In the rest of Serbia most of the companies invest averagely (grade 3) (36.11\%), while significant percentage $(27.78 \%)$ invest as much as they can (grade 5).

Value of factors which significantly influence export of products to $\mathrm{EU}$ is approximately equal for Zlatibor district and for the rest of Serbia. Most significant factor is product quality, followed by price, functionality, safety and product appearance characteristics. Distribution of management orientation to export to EU is also similar for Zlatibor district and for the rest of Serbia, whereby most of the managers (70 and 64\% in Zlatibor 
region and Serbia, respectively) have high grade of 4 and 5 in this matter.

Regarding information gathering about EU markets, there are certain differences between two regions. Half of the companies from Zlatibor region gather information promptly and other half not so much. On the other side, in the rest of Serbia, $63.89 \%$ of the companies stays up to date with all information regarding EU market. In Zlatibor region most common number of used sources of information varies from 1 to 5 , while in the rest of Serbia it is usually only one source.

Criteria for selection of countries for export are presented graphically, by the type of criterion and by the number of criterions that are used. Statistical analysis wasn't conducted, because of the small sample size from Zlatibor region. It is obvious that trend of market demands has the most important role in selection of countries for export (over $45 \%$ ). The next criteria are distribution channels with only $20 \%$. In the Zlatibor region, as well as in the rest of Serbia, companies most commonly use two criteria for selecting countries for export. Smaller percentage of companies use one criterion in the rest of Serbia, and in Zlatibor region the same percentage of companies use one, four and five criterion equally.

Possibility of products placement in certain countries in EU, among which Germany leads, followed by Slovenia, in most cases varies in the range of $10-20 \%$ to $20-40 \%$ of the production, and there isn't a significant difference between the Zlatibor region and the rest of Serbia.

Moreover, it is shown that a large number of surveyed companies did not know which directives they used $-72.22 \%$ in the rest of Serbia against $90 \%$ in the Zlatibor region. Nine companies (25\%), in Serbia, without the Zlatibor region, use one New Approach Directive, and three companies (8.33\%) use two directives. In the Zlatibor region, where $10 \%$ of the companies use New Approach and no one uses Old Approach, only one company gave more detailed information on the directive of the New Approach that they were using.

Most of the institutions that conduct products compliance are, in both regions, authorized/ appointed/notified bodies, followed by product manufacturers or their authorized representatives. Regarding the number of institutions which asses product compliance, in Zlatibor region as well as in the rest of Serbia, companies use one or at most two institutions, in the majority of cases (80-86\%).

Documents for assessment of products compliance that are used in this process are certificates and assessment reports. There is no significant difference in type of documents used in Zlatibor region and the rest of Serbia. As number of documents increases, in Zlatibor region, companies most commonly use three documents, while all companies use between one and three documents. In the rest of Serbia most companies use two to three documents, while for some companies that number increases to four.

CE sign has $70 \%$ of the surveyed companies in the Zlatibor region and $63,89 \%$ companies from the rest of Serbia. In Serbia, without Zlatibor region, most of the suppliers (over 70\%) have products that are in compliance with EU regulations. As for the surveyed companies from Zlatibor region, half of them doesn't know the answer while other half have all or some products that are in compliance with EU regulations.

Staying up to date with new regulations and with amendment and changes of the existing regulations practices more than half of companies in Serbia, without the Zlatibor region, namely $58.34 \%$. In the case of the Zlatibor region $30 \%$ of the companies continuously monitor these changes, while $40 \%$ occasionally check for new information.

When considering the use of modules for compliance with the directives, it can be seen that the use of the module A dominates. In Serbia, without Zlatibor region, the following is module $\mathrm{D}$, while within the Zlatibor region the use of modules $\mathrm{E}$ and $\mathrm{F}$ follows. In Serbia, without the Zlatibor region, most companies apply one module for compliance assessment, while in the Zlatibor region companies mostly apply 2 modules (figure 5.).

Five companies from Serbia, without Zlatibor region, which is $13.89 \%$, use $3-10$ additional standards, while in Zlatibor region only one company $(10 \%)$ uses additional standards.

When observing difficulties in both regions to fulfil formal requirements, as most challenging, companies depicted identification of required regulations and ensuring financial means for fulfilment of formal requirements. Other factors have a uniform grade. 
Most of the surveyed enterprises in the Zlatibor region as well as in the rest of Serbia believe that they should use the consulting services for fulfilment of formal requirements for export to the EU.

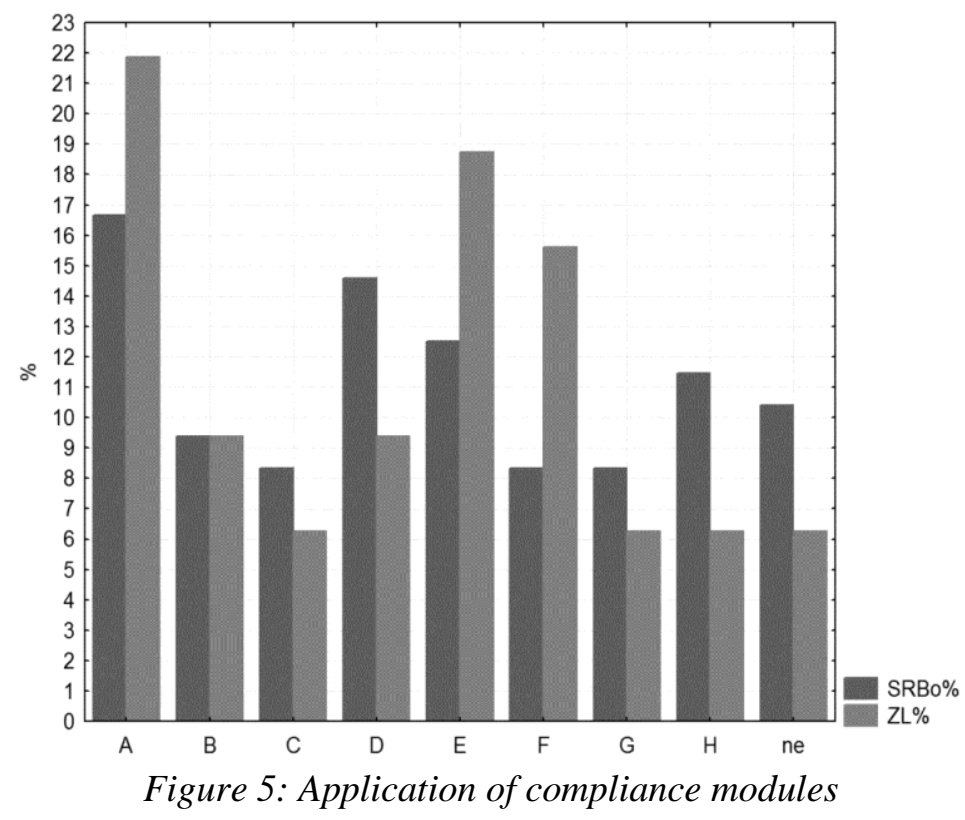

In the Zlatibor region most of the surveyed companies $(60 \%)$ believe that there is a sufficient number of laboratories and only $10 \%$ disagree. In the rest of Serbia $41.67 \%$ of the surveyed companies believe that there is a sufficient number of laboratories, and $36.11 \%$ disagree. In the Zlatibor region companies believe that there is a sufficient number of competent authorities (60\%), while in the rest of Serbia the prevailing opinion is that this number should be higher (41.67\%). In Serbia, without Zlatibor region, most of the surveyed companies $(66.67 \%)$ believe that there is a sufficient number of institutions to help exporters, while in the Zlatibor region this percentage is $50 \%$.

In the Zlatibor region, most of the surveyed companies $(70 \%)$ believe that investing resources in export activities is justified. In the rest of Serbia $36.11 \%$ companies think this type of investment is justified, while $41.67 \%$ do not know the answer to this question.

As most influential barrier for export to EU, companies from both regions have indicated a lack of government support and incentives, lack of capital to finance exports and the lack of information in locating and analysing the EU market. As the most important added value from the fulfilment of formal requirements for export to EU, companies in Serbia and Zlatibor region primarily see an increase in sales, followed by a larger number of customers and incensement of product quality.

\section{CONCLUSIONS}

Comparative analysis on the export capabilities of the Zlatibor region and the rest of Serbia, presented in this paper, indicates the following. Companies in Zlatibor region are distributed differently through sub-sectors compared to the rest of Serbia. There is a small number of significant differences between the barriers which could influence the difference in export capabilities of the Zlatibor region and the rest of Serbia. It is important to emphasize the fact that a large number of surveyed companies is not familiar with directives they use, that is, $72.22 \%$ in the rest of Serbia, against $90 \%$ in the Zlatibor region. Thus, in the Zlatibor region, where $10 \%$ of companies use New Approach, only one company gave additional information on the directive of the New Approach that they use. This indicates that the companies hire consultants or subcontract export arrangements, which definitely reduce their chances of success on foreign markets. The situation is similar with regard to suppliers of components and materials incorporated into the products to be exported - in Serbia, without the Zlatibor region, $70 \%$ of suppliers have products that are in compliance with EU legislation, while only half of the companies from Zlatibor region 
have products or part of products in compliance with EU legislation. Also, companies from Zlatibor region are less effective in tracking the emergence of regulations and amending and changing of existing regulations, which is significant contributor for export capabilities. As Spasojević Brkić et al. (2011) noticed before, quality management factors are reliable and valid instruments for predicting total factor productivity, while Castellani (2002) proves that export behavior and productivity growth are closely connected, so Serbian companies, including those in Zlatibor region, according to the results of this survey, also have to pay more attention to issues connected to regulative.

\section{ACKNOWLEDGEMENT}

This work is supported by grants TR 35017 (MESTD) and Research on formal requirements for export products on EU market in the cross border area in Bosnia and Serbia, Ref: 2012/306285/TD 11 (RRA Zlatibor).

\section{REFERENCES}

Baldauf, A., Cravens, D. W., \& Wagner, U. (2000). Examining determinants of export performance in small open economies. Journal of World Business,35(1), 61-79.

Basile, R. (2001). Export behaviour of Italian manufacturing firms over the nineties: the role of innovation. Research policy, 30(8), 1185-1201.

Bonaccorsi, A. (1992). On the relationship between firm size and export intensity. Journal of international business studies, 605-635.

Castellani, D. (2002). Export behavior and productivity growth: Evidence from Italian manufacturing firms. Weltwirtschaftliches Archiv, 138(4), 605-628.

Ćoćkalo, D., Đorđević, D., Sajfert, Z., \& Bogetić, S. (2011). SMEs in the Republic of Serbia: The developing capacities. Journal of Applied Engineering Science, 9(4), 449-456.

Donthu, N., \& Kim, S. H. (1993). Implications of firm controllable factors on export growth. Journal of Global Marketing, 7(1), 47-64.

Đorđević, D., Ćoćkalo, D., \& Đurin, S. (2011). Serbian Enterprises and Global Competition Challenges. Journal of Engineering Management and Competitiveness (JEMC), 1(1/2), 27-31.

Jakopin, E., \& Bajec, J. (2009). Challenges of industrial development of Serbia. Panoeconomicus, 56(4), 507-525.
Khara, N., \& Dogra, B. (2009). Examination of export constraints affecting the export performance of the Indian sports goods industry. European Journal of International Management, 3(3), 382-392.

Knudsen, T., \& Madsen, T. K. (2002). Export strategy: a dynamic capabilities perspective. Scandinavian Journal of Management, 18(4), 475-502.

Kumlu, Ö. (2014). The effect of intangible resources and competitive strategies on the export performance of small and medium sized enterprises. Procedia-Social and Behavioral Sciences, 150, 2434.

Lee, C., \& Griffith, D. A. (2004). The marketing strategy-performance relationship in an exportdriven developing economy: A Korean illustration. International Marketing Review, 21(3), 321-334.

Leonidou, L. C., Katsikeas, C. S., Palihawadana, D., \& Spyropoulou, S. (2007). An analytical review of the factors stimulating smaller firms to export: Implications for policy-makers. International Marketing Review, 24(6), 735-770.

Leonidou, L. C., Katsikeas, C. S., \& Coudounaris, D. N. (2010). Five decades of business research into exporting: a bibliographic analysis. Journal of International Management, 16(1), 78-91.

Papadopoulos, N., \& Martín, O. M. (2010). Toward a model of the relationship between internationalization and export performance.International Business Review, 19(4), 388-406.

Savić, M., Đorđević, P., Nikolić, Đ., Mihajlović, I., \& Živković, Ž. (2012). Combination of knowledge in the system suppliers-MSP-customers in the transitional economy environment in Serbia. Journal of Applied Engineering Science, 10(4), 227-233.

Spasojevic Brkic, V., Dondur, N., Klarin, M., Komatina, M., \& Curovic, D. (2011). Effectiveness of quality management and total factor productivity. African Journal of Business Management, 5(22), 9200-9213.

Spasojević-Brkić, V. K., Veljković, Z. A., Golubović, T., Omić, S., \& Brkić, A. Đ. (2014). Bosnia and Herzegovina's metalworking industry companies barriers to export to EU market. Journal of engineering management and competitiveness (JEMC), 4(2), 78-84.

Spasojević-Brkić, V., Veljković, Z., \& Golubović, T. (2015). Fulfilling the requirements for export of metal industry products from Serbia and Bosnia and Herzegovina cross-border area to EU market. Journal of Applied Engineering Science, 13(1), 2536.

Stoian, M. C., Rialp, A., \& Rialp, J. (2011). Export performance under the microscope: A glance through Spanish lenses. International Business Review, 20(2), 117-135. 


\title{
KOMPARATIVNA ANALIZA IZVOZNE SPOSOBNOSTI PREDUZEĆA METALSKOG KOMPLEKSA ZLATIBORSKOG OKRUGA I OSTATKA SRBIJE
}

\begin{abstract}
Izvoz je vrlo značajna aktivnost za kompanije čije je sedište u zemljama u razvoju, dok je prerađivačka industrija najvažniji sektor EU ekonomije koji utiče na njen rast i pokreće njen tehnološki i inovativni razvoj, tako da je za očekivati da je izvoz ovog sektora veoma važna aktivnost sa nacionalne tačke gledišta. U skladu sa tim, tema ovog istraživanja su izvozne mogućnosti metalskog kompleksa i poređenje izvoznih sposobnosti preduzeća metalskog kompleksa Zlatiborskog okruga i ostataka Srbije na tržište EU. Značajnih razlika između barijera koje bi uticale na razlike u izvoznoj sposobnosti Zlatiborskog okruga i ostatka Srbije je malo, tačnije razilke su uglavnom u nivou poznavanja regulative. Značajan broj preduzeća nije upoznat sa direktivama novog pristupa, kao ni sa procedurama ocenjivanja usaglašenosti. Takođe, preporuka je pažljiviji izbor dobavljača koji zadovoljavaju neophodne zahteve.
\end{abstract}

Ključne reči: izvoz na tržište EU, formalni zahtevi za izvoz, razlike, izvozne barijere 